\title{
Antibacterial Efficacy of Commercial Disinfectants on Dirt Floor Used in Poultry Breeder Houses
}

- Author(s)
Pilotto $F^{1}$
Rodrigues $L^{2}$
Santos $L^{2}$
Klein WA ${ }^{2}$
Colussi FM 2,3
Nascimento VP4

1 Faculdade de Agronomia. Programa de Pós-
Graduação em Zootecnia. Universidade
Federal do Rio Grande do Sul - UFRGS. Porto
Alegre, RS, Brasil.
2 Faculdade de Agronomia e M edicina
Veterinária da Universidade de Passo Fundo
- UPF, Passo Fundo, RS, Brasil.
3 Bolsista FAPERGS.
4 Faculdade de Veterinária da Universidade
Federal do Rio Grande do Sul - UFRGS. Porto
Alegre, RS, Brasil.

Mail Address

Fernando Pilotto

Rua do Ipê, 403

Condomínio Morada Além do Horizonte

CP 131

99.064-991. Passo Fundo, RS, Brasil

E-mail: fernando.pilottouol.com.br

Keywords

Antimicrobial activity, dirt floor, disinfectants, poultry breeder houses.

\section{ABSTRACT}

Dirt floors are used on most Brazilian poultry farms since the construction of concrete floors is very expensive. In vitro tests carried out to verify the effectiveness of disinfectants do not consider the adverse conditions found in poultry farms. Therefore, the present study aimed at evaluating the effect of six commercial disinfectants on the reduction of total and fecal coliforms on the dirt floor of breeder houses. The amount of disinfectant solution to be used per square meter was defined by counting total and fecal coliforms at different soil depths and by analyzing soil physical properties. Coliforms were detected at $0.5 \mathrm{~cm}$, and one liter of disinfectant solution was sufficient for soil saturation at this depth. After that, the efficacy of six commercial products (caustic soda, hydrated lime, phenols 1 and 2, iodine, glutaraldehyde, and quaternary ammonium) in reducing the number of coliforms, after six hours of contact with the dirt floor, was assessed using the most probable number (MPN) method. Escherichia coli specimens isolated from the dirt floor were used to evaluate in vitro effectiveness of disinfectants. Products that yielded the best results in the MPN method were also effective in the in vitro tests. Among the tested disinfectants, hydrated lime was the most efficient, reducing the initial contamination by 2.9 log after six hours of contact with the dirt floor.

\section{INTRODUCTION}

Cleaning and disinfection established in poultry farms, in compliance with sanitation control procedures, ensure farm animal health, as in confined animal facilities, the frequency of diseases and their severity are directly related to the level of environmental contamination (Siqueira, 1995).

Due to the high cost of the construction of concrete floors for poultry houses in Brazil, the disinfection of the dirt floor is a critical point, because the removal of organic matter, which reduces the antimicrobial activity of disinfectants, is not simple (Ruano et al., 2001). In addition, in vitro tests do not consider the adverse conditions found in poultry farms (Sobestianski, 2002). M organ-Jones (1987) asserts that such tests would help to determine the efficacy of disinfectants, but recommend detecting and counting microorganisms in the field in order to verify the actual effect of the products used.

Logan \& Bartlet (2001) demonstrated that after cleaning and disinfection of a dirt floor, only the top layer was moderately decontaminated. The same authors, testing the effectiveness of disinfectants using MPN method before and after the use of these products, observed a 98\% decrease in bacterial count at a depth of $1.37 \mathrm{~cm}$. Paganini (2002) mentions that the disinfection of a dirt floor does not remove microorganisms from deeper soil layers, as the amount 
Pilotto F, Rodrigues LB, Santos LR, Klein WA, Colussi FM, Nascimento VP

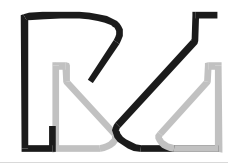

of disinfectant needed to reach these layers is not known. Ruano et al. (2001) verified that most disinfectants are effective in the absence of organic matter, but that contact time and the amount recommended by the manufacturer have to be increased in order to maintain their efficacy in the presence of organic matter. For Romero (1970), the weak presence of organic matter on deeper soil layers, the lower oxygen supply due to soil compaction, and the poor ability to compete with the soil flora are adverse conditions for coliform growth.

Coliform bacteria are used as bacteriological indicators to define the patterns for controlling the quality of the water and foods for human consumption (Delazari, 1998). Total coliform count is used to assess sanitation conditions, where high counts mean poor cleanliness and sanitation or post-processing contamination (Sander, 2002), whereas fecal coliforms indicate contamination by E. coli (Paganini, 2004). The most probable number (MPN) method provides information about the population of total and fecal coliforms and, as it is more sensitive than plate counts, it is indicated for the detection of small numbers of coliforms (APHA, 1980).

Therefore, this work aimed at verifying the antimicrobial activity of six commercial disinfectants on dirt floor through the use of MPN, and to compare the results of in vitro tests.

\section{MATERIALS AND METHODS}

The study was conducted in poultry breeder house in the state of Rio Grande do Sul, Brazil. Samples were collected 24 hours after litter removal. Poultry house dimensions were $120 \mathrm{~m} \mathrm{X} 12 \mathrm{~m}$, with an area of $63 \mathrm{~m}$ $X 3 \mathrm{~m}$ next to one of the barn sides. This area was split into three blocks of $21 \times 3$ meters, each subdivided into seven $1 \mathrm{~m}^{2}$ areas 2-m distant from each other. The experiment was carried out in four phases:

1) total and fecal coliform counts of soil samples at different depths,

2) determination of the amount of disinfectant needed to saturate an area at a given depth,

3) assessment of the efficacy of six commercial disinfectants used on dirt floor,

4) in vitro assessment of the efficacy of these disinfectants against $E$. coli specimens isolated during the first phase of the study.
Antibacterial Efficacy of Commercial Disinfectants on Dirt Floor Used in Poultry Breeder Houses

\section{Total and fecal coliform counts in soil samples at different depths}

Five soil samples were collected at five different sites from each of the blocks, totaling 15 samples. An Uhland soil sampler with sterile stainless steel cylinders measuring $50 \mathrm{~mm} \times 50 \mathrm{~mm}$ was used (Klein, 1998). Soil blocks were manually pressed out of the cylinders, and cut into $0.5-\mathrm{cm}$ layers with a knife blade. Therefore, four samples w ere collected from each block, three at each depth $(0$ to $0.5 \mathrm{~cm}, 0.5$ to $1 \mathrm{~cm}, 1$ to 1.5 $\mathrm{cm}$ and 1.5 to $2 \mathrm{~cm}$ ) totaling 12 samples. Samples were stored in sterile plastic bags, and then taken to the laboratory to determine coliform numbers, i.e., total and fecal coliform counts using MPN (Sander, 2002).

\section{Determination of the amount of disinfectant needed to saturate an area at a given depth}

Five soil samples were collected at different sites from each of the three blocks. Organic matter content was determined by sulfochromic oxidation, as described by Tedesco (1995). Particle size composition was obtained using the method developed by Gee \& Bauder (1986), whereas soil density, total porosity, and humidity were determined according to the Manual on Soil Sampling and Methods of Analysis (Embrapa, 1997). In order to determine the solution volume to be applied to a given area, we used gravimetric water content as a function of soil density, which allowed us to calculate volumetric water content. The amount of water necessary for saturation was based on volumetric water content and on total porosity. The difference between these two parameters indicated the amount of pores that still could be water-filled. After determining the layer that should be saturated, we calculated the amount of water to be added per $\mathrm{m}^{2}$ (Libardi, 2005) using the soil water storage equation. These physical and hydro parameters allowed the calculation of the amount of disinfectant needed to saturate the dirt floor down to the desired depth (Klein, 1998), i.e., up to the point at which coliforms could be detected in the first phase of the study.

\section{Assessment of the efficacy of six commercial disinfectants used on dirt floor}

Six commercially available products were tested: hydrated lime $\left(\mathrm{CaOH}_{2} 90.46 \%\right)$, caustic soda $(\mathrm{NaOH}$ $98 \%$ ), quaternary ammonium compounds with glutaraldehyde (benzalkonium chloride $50 \%$ and glutaraldehyde $50 \%$ ), iodine $2.6 \%$, phenol 1 (phenols 
Pilotto F, Rodrigues LB, Santos LR, Klein WA, Colussi FM, Nascimento VP

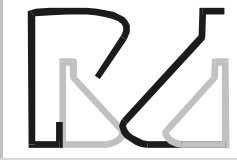

Antibacterial Efficacy of Commercial Disinfectants on Dirt Floor Used in Poultry Breeder Houses
$10.5 \%$, cresols $10.5 \%$ ) and phenol 2 (orthophenylphenol $12.12 \%$, orthobenzyl parachlorophenol $10.52 \%$, para-tertiary aminophenol $4.06 \%$ ). These products were tested in triplicate in the three blocks defined in the first phase of the study, and one block was defined as control in each block of $1 \mathrm{~m}^{2}$ seven areas. Three soil samples were collected from each $1 \mathrm{~m}^{2}$ area at three different sites at a depth of $0.5 \mathrm{~cm}$. Disinfectants were diluted according to the manufacturer's instructions, as follows: phenol 1 (1:40), phenol 2 (1:256), iodine (1:320), quaternary ammonium with glutaraldehyde $(1: 1000)$, caustic soda $(2.2 \%)$, and hydrated lime $(20 \%)$. The efficacy of the disinfectants was assessed by counting the number of coliforms, i.e, total and fecal coliform counts six hours before and after the application of the product (Siqueira, 1995).

\section{In vitro assessment of disinfectant efficacy}

The Escherichia coli specimens isolated during the study were used to assess disinfectant efficacy, according to the Methods of Analysis for the Control of Products of Animal Origin and Their Ingredients (Brasil, 1993). Disinfectants were diluted according to the manufacturer's instructions, and $9 \mathrm{ml}$ of each disinfectant solution was dispensed into sterile test tubes, with addition of whole UHT milk. We added $0.1 \mathrm{~mL}$ of the test culture in stationary phase, diluted $1: 100$, to the tubes containing the diluted disinfectant, homogenized it, and set contact times at 5, 10, 15 and 20 minutes. Afterwards, using a $10-\mu \mathrm{L}$ calibrated loop, we transferred the solution to tubes containing $10 \mathrm{ml} \mathrm{BHI} \mathrm{broth,} \mathrm{which} \mathrm{were} \mathrm{incubated} \mathrm{at} 37^{\circ} \mathrm{C}$ for 96 hours, and checked for turbidity and biofilm formation on the surface or for precipitation at the bottom of the tubes. These samples were seeded onto EM B agar plates, and the colonies were subjected to biochemical confirmation.

\section{Statistical Analysis}

M PN values were transformed into logarithms, and submitted to analysis of variance using a randomized block design. Means were compared using Tukey's test $(P=0.05)$. Data were processed by Minitab for Windows version 11.1 .

\section{RESULTS AND DISCUSSION}

The results obtained using MPN relative to total and fecal coliform counts in the dirt floor at different depths show ed that only the first of the four $0.5-\mathrm{cm}$ superficial layers indicated the presence of total and fecal coliforms, with an average of $1,100 \mathrm{MPN} / \mathrm{g}$ and 460 $M P N / g$, respectively. In layers with depth between 0.5 and $2.0 \mathrm{~cm}$, coliform number was lower than $3 \mathrm{M} \mathrm{PN/}$ $g$. These results show their possible absence, since this is the smallest possible MPN value.

The detection of coliforms at $0.5 \mathrm{~cm}$ may be ascribed to the fact that this layer is in direct contact with poultry droppings, and even after litter removal and cleaning of the floor, feces and wood shavings may remain in the environment (Romero, 1970). In the present study, organic matter content on the top layer (depths between 0 and $0.5 \mathrm{~cm}$ ) amounted to $6.7 \%$, whereas on the remaining layers (depths between 0.5 and 2 $\mathrm{cm}$ ) it averaged $1.67 \%$. Logan \& Bartlet (2001), after evaluating the contamination of dirt floor by coliforms, found $1,900 \mathrm{MPN} / \mathrm{g}$ at a depth of $0.6 \mathrm{~cm}$ and $460 \mathrm{MPN} /$ $\mathrm{g}$ at $1.2 \mathrm{~cm}$, demonstrating that contamination diminishes as depth increases. The presence of coliforms on the deepest layers of the dirt floor depends on soil type and on soil compaction caused by earthmoving activities. Sandy soils are more porous than clay soils, and therefore are more susceptible to deeper contamination (Kzar, 1988; Martinez et al., 1999). The present study was conducted on a clay soil, which is characterized by low porosity and good compaction. The higher levels of contamination observed by Logan \& Bartlet (2001) may be due to the physical properties of the soil, although these authors did not describe them. For Paganini (2002), disinfection of dirt floors is not effective at deeper soil depths as the amount of disinfectant necessary to saturate the soil is not known, and also because of the absent or limited effect of these products in the presence of organic matter. Thus, in the first phase of the present study, the necessary amount of disinfectant was defined by counting coliforms at different soil depths, and by assessing the physical and hydraulic properties of the soil. Coliforms were detected at up to $0.5 \mathrm{~cm}$, and one liter was considered to be sufficient to saturate the soil.

Among the six disinfectants used in the field trial evaluation (Table 1), hydrated lime yielded the best results, reducing initial contamination by $2.9 \mathrm{log}$ $(p=0.0001)$. No significant difference was observed between caustic soda, phenols 1 and 2, iodine, orquaternary ammonium and glutaraldehyde. The reduction of total and fecal coliforms obtained with hydrated lime was similar to those found by Ide (1994), who reported reductions of 3.18 logs for total coliforms and of 2.94 log for fecal coliforms. Nevertheless, Huber (1992) stated that organic matter reduces the effect of hydrated lime. 


\section{Pilotto F, Rodrigues LB, Santos LR, Klein WA, Colussi FM, Nascimento VP}

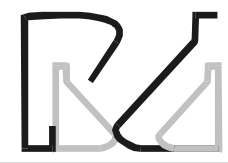

Antibacterial Efficacy of Commercial Disinfectants on Dirt Floor Used in Poultry Breeder Houses
Both phenol compounds showed different antibacterial effects on coliforms. This finding is consistent with Martinez et al. (1999), who observed some differences between compounds with the same active ingredient when assessing the effects of phenols on Salmonella, and concluded that these findings resulted from the dilutions recommended by the manufacturers and from the different concentrations of the active ingredients.

\begin{tabular}{|c|c|c|c|c|}
\hline \multirow[t]{2}{*}{ Commercial products } & \multicolumn{2}{|c|}{ MPN/g in log units } & \multicolumn{2}{|c|}{ Reduction } \\
\hline & before & $\begin{array}{l}\text { after } \\
6 \text { hours }\end{array}$ & $\log$ & $\%$ \\
\hline Caustic soda $(2.2 \%)$ & $3.21^{\mathrm{a}}$ & $2.39^{\mathrm{a}}$ & 0.82 & 84.87 \\
\hline Hydrated lime & $3.38^{a}$ & $0.47^{b}$ & 2.90 & 99.87 \\
\hline Phenol $1(1: 40)$ & $3.08^{a}$ & $3.29^{a}$ & -0.22 & -69.30 \\
\hline Phenol 2 (1:256) & $3.04^{a}$ & $2.91^{\mathrm{a}}$ & 0.13 & 25.33 \\
\hline lodine $(1: 320)$ & $3.00^{\mathrm{a}}$ & $3.38^{a}$ & -0.38 & -139.21 \\
\hline $\begin{array}{l}\text { Quaternary ammonium } \\
\text { with glutaraldehyde }(1: 1000)\end{array}$ & $2.95^{\mathrm{a}}$ & $3.38^{\mathrm{a}}$ & -0.43 & -170.67 \\
\hline Control (water) & $3.04^{a}$ & $3.38^{\mathrm{a}}$ & -0.34 & -116.86 \\
\hline
\end{tabular}

$a, b, c$ : Different letters in the same row and column indicate statistically significant difference (Tukey's test $P=0.05$ ). (-): a negative percentage value means that the number of microorganisms increased after six hours of treatment. (MPN/g in log units): Most probable number of microorganisms per gram of dirt floor in decimal logarithm.

lodine was inefficient in reducing coliform M PN. This finding is in agreement with that obtained by Gloaguen (1980), who reported the poor effect of this disinfectant in the presence of organic matter. Martinez et al. (1999) showed the inefficacy of five iodine-containing disinfectants on Salmonella when $10 \%$ of bird feces were added to the disinfectant solution.

The use of two or more active ingredients in commercial disinfectants is expected to increase the antibacterial effect of these products. Products containing quaternary ammonium and/or glutaraldehyde have been the most widely used for disinfection of poultry houses (Cardoso, 2000). However, in the present study, this product was not successful in reducing coliform M PN. M oreover, Huber (1992) stated that products containing quaternary ammonium result in a quick selection of resistant microorganisms.

The in vitro assessment of the effect of disinfectants on $E$. coli specimens isolated during the study revealed that caustic soda, hydrated lime, and phenols 1 and 2 were efficient at all contact times $(5,10,15$, and 20 minutes), while iodine and quaternary ammonium with glutaraldehyde did not have any antimicrobial activity (Table 2). The in vitro method has advantages, but also some disadvantages, in assessing the efficacy of disinfectants. The major advantage is that it allows checking whether the analyzed strains differ in terms of resistance to the disinfectants tested (Andrade et al., 1998). How ever, although the method can be used to simulate the antimicrobial activity of disinfectants, it does not reproduce the actual usage conditions on poultry farms (M organ-Jones, 1987). In this experiment, the in vitro and field test results were similar (except for phenol 1); how ever, according to the literature, the efficacy of disinfectants under field conditions applied to the natural microbiota or to the strains of microorganisms artificially inoculated onto soil surfaces is much lower than on suspension tests. Moreover, even if the resistance of strains to the different active ingredients of disinfectants turns out to be similar, differences in adhesion and biofilm formation may interfere with the efficacy of disinfectants (Andrade et al., 1998; Costa, 1999; Hood \& Zottola, 1997).

\begin{tabular}{|c|c|c|c|c|}
\hline \multirow{2}{*}{ Commercial products } & \multicolumn{4}{|c|}{ Contact time (in minutes) } \\
\hline & 5 & $10^{4}$ & 15' & 20' \\
\hline Caustic soda $(2.2 \%)$ & - & - & - & - \\
\hline Hydrated lime $(20 \%)$ & - & - & - & - \\
\hline Phenol $1(1: 40)$ & - & - & - & - \\
\hline Phenol 2 (1:256) & - & - & - & - \\
\hline lodine $(1: 320)$ & + & + & + & + \\
\hline $\begin{array}{l}\text { Quaternary ammonium with } \\
\text { glutaraldehyde 1:1000 }\end{array}$ & + & + & + & + \\
\hline Control & + & + & + & + \\
\hline
\end{tabular}

Sander (2002) reports that microorganisms isolated from hatcheries show different sensitivity levels to disinfectants as compared to standard samples. Eiroa $\&$ Porto (1995) mentioned that disinfectants of different brands and with the same active ingredient have different antimicrobial activity. According to Tamasi (1995), the in vitro method requires the use of standard strains considered to be representative. However, these strains are not influenced by external factors, such as transfer of resistance genes, physiological injuries due to prolonged use, underdosage, and presence of organic matter, which may lead to the development of resistance. Thus, the assessment of the efficacy of disinfectants should not be restricted to in vitro tests and field trials with drag swabs, agar pour plate, or total count of microorganisms should be used to evaluate the actual effect of the products employed. According to Sander (2002), it is also 


\section{Pilotto F, Rodrigues LB, Santos LR, Klein WA, Colussi FM, Nascimento VP}

Antibacterial Efficacy of Commercial Disinfectants on Dirt Floor Used in Poultry Breeder Houses

important to consider that field samples allow the identification of bacteria and testing the sensitivity of these microorganisms to commercially available disinfectants.

Programs for the disinfection of poultry farms use hydrated lime to provide higher light intensity for the birds, and to improve the appearance of the farm. However, according to the present study, hydrated lime was more efficient than the currently available disinfectants. So, it can be inferred that the disinfection of poultry houses with commercial disinfectants was perhaps improved with the subsequent use of hydrated lime, as some disinfectants did not present any antibacterial activity in the present study.

\section{REFERENCES}

American Public Health Association. Standard methods for the examination of water and wastewater. $15^{\text {th }}$ ed. New York: APHA/ AWWA; 1980.

Andrade NJ, Bridgeman TA, Zotttola EA. Bactericidal activity of sanitizers against Enterococcus faecium attached to stainless steel as determined by plate count and impedance methods. Journal of Food Protection 1998; 61:833-838.

Brasil. M inistério da Agricultura e Abastecimento. Métodos analíticos para controle de produtos de origem animal e seus ingredientes. Brasília: CGLA-DDA; 1993.

Cardoso MO. Avaliação da sensibilidade a antimicrobianos e eficiência de desinfetantes em amostras de Salmonella Enteritidis isoladas de carcaças de frangos no Estado do Rio Grande do Sul [dissertação]. Porto Alegre (RS): UFRGS; 2000.

Costa ETR. Desenvolvimento de metodologia para detecção da adesão microbiana em superfície inoxidável [dissertação]. Rio de Janeiro: UFRRJ; 1999.

Delazari I. Aspectos microbiológicos ligados à segurança e qualidade da carcaça de aves. In: Semana Acadêmica Veterinária, 8; 1998; São Paulo. p.71-77.

Eiroa MNU, Porto E. Evaluation of different chlorine based disinfectants and vinegar against Vibrio cholerae presence in lettuce. Coletânea do ITAL 1995; 25:169-172.

Embrapa. Empresa Brasileira de Pesquisa Agropecuária. Centro Nacional de Pesquisa de Solos. Manual de métodos de análise de solo. 2.ed. Rio de Janeiro; 1997.

Gee GW, Bauder JW. Particle size analysis. In. Klute A, editor. Methods of soil analysis: physical, chemical and mineralogical methods. Madison: American Society of Agronomy; 1986. cap. 15, p.383-411.

Gloaguen Y. La desinfection un Interêt incontestable - les desinfectantes: à choisir parmi les bons produits. L'Éleveur de Porcs 1980; 117:15-19.
Hood SK, Zottola EA. Growth media and surface conditioning influence the adherence of Pseudomonas fragi, Salmonella typhimurium and Listeria monocytogenes cells to stainless steel. Journal of Food Protection 1997; 60:1034-1037.

Huber GW. Anti-sépticos e Desinfetantes. In: Booth NH, McDonald LE. Farmacologia e terapêutica em veterinária. 6.ed. Rio de Janeiro: Guanabara Koogan; 1992. cap. 47, p.617-632.

Ide CE. Eficiência da estabilização de lodos de ETEs com cal e ferrato (VI) de potássio [tese] Porto Alegre (RS):UFRGS; 1994.

Klein VA. Propriedades físico-hídrico-mecânicas de um Latossolo Roxo, sob diferentes sistemas de uso e manejo [tese] Piracicaba: ESALQ; 1998. 150p.

Kzar AE. A água no sistema solo-planta-atmosfera. 2 ed. São Paulo: Nobel; 1988.

Libardi PL. Dinâmica da água no solo. São Paulo: EDUSP; 2005. 335p.

Logan M, Bartlet S. Evaluation of coliform removal at $1 / 2$ inch depth of poultry house floor using Impact-S process. Virginia: Environmental Dynamics; 2001. 41 p.

Martinez F, Berchieri Jr A, Paulillo AC. A ção de desinfetantes sobre Salmonella na presença de matéria orgânica. Revista Brasileira de Ciência Avícola 1999; 1:17-25.

Morgan-Jones S. Practical aspects of disinfection and infection control. In: Linton, AH, editor. Disinfection in veterinary and practice. England, UK: Blackwell Scientific Publication; 1987. p.144-147.

Paganini FJ. Reutilização de cama na produção de frangos de corte: porquê, quando e como fazer. In: Conferência A pinco de Ciência e Tecnologia; 2002; Campinas. p 195-206.

Paganini FJ. Manejo da cama. In: Mendes AA, Naas EA, Macari M. Produção de frangos de corte. Campinas: Facta; 2004. cap. 7, p. 107-115.

Romero LC. The movement of bacteria and viruses through porous media. Ground Water 1970; 8:37-47.

Ruano M, El-Attrache J, Villegas P. Efficacy comparison of disinfectants used by the commercial poultry industry. Avian Diseases 2001; 45:972-977.

Sander JE. Investigation of resistance of bacteria from commercial poultry sources to commercial disinfectants. Avian Diseases 2002; 46:997-1000.

Siqueira RS. Manual de microbiologia de alimentos. Rio de Janeiro: Embrapa, Centro Nacional de Pesquisa de Tecnologia Agroindustrial de Alimentos; 1995.

Sobestianski J. Sistema intensivo de produção de suínos: programa de biossegurança. Goiânia: Art 3. 2002; 108p.

Tamasi G. Testing disinfectants for efficacy. Revue Scientifique et Technique 1995; 14:75-79.

Tedesco MJ. Análise do solo, plantas e outros materiais [dissertação]. Porto Alegre (RS): UFRGS; 1995. 